\title{
THE HEPATIC BLOOD FLOW IN RESTING HYPERTENSIVE PATIENTS BEFORE AND AFTER SPLANCHNICECTOMY ${ }^{1}$
}

\author{
By ROBERT W. WILKINS, JAMES W. CULBERTSON,² AND ADELE A. RYMUT \\ (From the Robert Dawson Evans Memorial, Massachusetts Memorial Hospitals and the De-
} partment of Medicine, Boston University School of Medicine, Boston, Mass.)

(Submitted for publication December 14, 1951 ; accepted March 24, 1952)

\section{INTRODUCTION}

Studies of blood flow and calculations of peripheral resistance in various vascular regions of hypertensive patients have generally shown the first to be normal and the second to be increased. With the introduction of the bromsulfalein (BSP) extraction method (2), it became possible to measure the circulation in the last important unexplored region, namely, the hepatic-portal, which represents the splanchnic system exclusive of the renal and adrenal circuits. The purpose of this paper is to report the estimated hepatic blood flow (EHBF) and the calculated hepatic-portal resistance (HPR) in a group of hypertensive as compared with a group of normotensive persons, and in some of the same hypertensive patients at various intervals after, as compared with before, surgical (usually lumbodorsal) splanchnicectomy.

\section{METHODS}

The methods were identical with those already reported in studies on the effects of the upright posture (3, 4). EHBF was measured only after all apparatus had been smoothly operating and the subject had been quietly resting (recumbent) for at least 20 minutes. Hepatic-portal resistance (HPR) was calculated simply by dividing the "mean" (one-half systolic plus diastolic) arterial pressure by the EHBF per second.

\section{RESULTS}

Table I shows a statistical analysis of $\mathrm{EHBF}$ and HPR in 41 hypertensive patients as compared with 21 normotensive persons concurrently studied by identical methods in this laboratory. It is

1 Presented in part May 5, 1947 at the Thirty-Ninth Annual Meeting of the American Society for Clinical Investigation, Atlantic City, New Jersey (1).

2 Public Health Service, Special Research Fellow of the National Heart Institute. Present. position-Assistant Professor of Internal Medicine and Director of Cardiovascular Research Laboratories, College of Medicine, State University of Iowa, Iowa City, Iowa. evident that EHBF was not significantly different, whereas arterial pressure and hence HPR were significantly higher in the hypertensive as compared with the normotensive group.

Table II shows that on statistical analysis $\mathrm{EHBF}$ in 13 hypertensive patients two weeks after splanchnicectomy was definitely higher, and HPR significantly lower than before operation. However, as Table III demonstrates, in a group of six hypertensive patients the increased EHBF and HPR returned within four to ten months after operation to essentially preoperative levels. Figure 1 is a chart of the results in one hypertensive patient studied before, and two weeks, ten months, and two years after splanchnicectomy. It illustrates the same trends as shown in Tables II and III.

\section{SUMMARY AND CONCLUSIONS}

1. Estimated hepatic blood flow (EHBF) is not significantly different and hepatic-portal resistance (HPR) is significantly higher in hypertensive than in normotensive persons.

2. Shortly after splanchnicectomy EHBF is increased and HPR is decreased as compared with

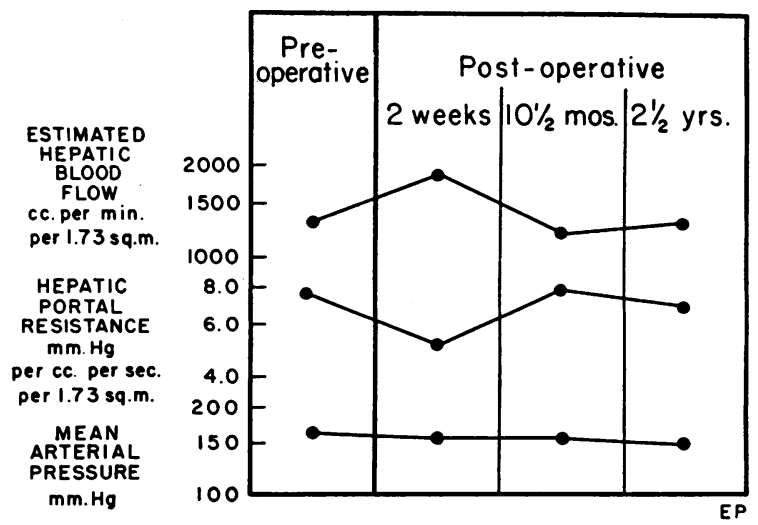

Fig. 1. Chart of the Effects of Lumbodorsal. Splanchnicectomy on the Hepatic-Portal Circulation in a Hypertensive Patient 
TABLE I

A comparison between the estimated hepatic blood flow (EHBF), arterial pressure, and hepatic-portal resistance (HPR) of 21 normotensive and 41 hypertensive patients

\begin{tabular}{|c|c|c|c|c|c|c|}
\hline & \multicolumn{2}{|c|}{$\underset{(c c . / m i n . / 1.73 \text { sq. m. })}{\text { EHBF }}$} & \multicolumn{2}{|c|}{$\begin{array}{c}\text { Mean arterial pressure } \\
(m m . H g)\end{array}$} & \multicolumn{2}{|c|}{$\begin{array}{c}\text { HPR } \\
(\mathrm{mm} . \mathrm{Hg} / \mathrm{cc} . / \mathrm{sec} . / 1.73 \mathrm{sq} . \mathrm{m} .)\end{array}$} \\
\hline & Mean & $\begin{array}{l}\text { Standard } \\
\text { error }\end{array}$ & Mean & $\begin{array}{l}\text { Standard } \\
\text { error }\end{array}$ & Mean & $\begin{array}{l}\text { Standard } \\
\text { error }\end{array}$ \\
\hline $\begin{array}{l}\text { Normotensives } \\
\text { Unoperated hypertensives } \\
\text { Difference }\end{array}$ & $\begin{array}{r}1,381 \\
1,303 \\
-78\end{array}$ & $\begin{array}{l}78 \\
50 \\
85\end{array}$ & $\begin{array}{r}100 \\
162 \\
+62\end{array}$ & $\begin{array}{l}2 \\
4 \\
4\end{array}$ & $\begin{array}{r}4.7 \\
8.0 \\
+3.3\end{array}$ & $\begin{array}{l}0.3 \\
0.4 \\
0.5\end{array}$ \\
\hline Significance of difference $\left(\mathrm{P}^{*}\right)$ & \multicolumn{2}{|c|}{0.37} & \multicolumn{2}{|c|}{$<0.01$} & \multicolumn{2}{|c|}{$<0.01$} \\
\hline
\end{tabular}

* P values of 0.05 or less indicate statistically "significant" differences; values of 0.01 or less are "highly significant."

TABLE II

The early effects of splanchnicectomy upon estimated hepatic blood flow (EHBF), arterial pressure, and hepatic-portal resistance (HPR) in a group of 13 hypertensive patients

Before operation

Two weeks after operation

Difference

Significance of difference $(P)$

\begin{tabular}{|c|c|c|c|}
\multicolumn{2}{|c|}{$\begin{array}{c}\text { EHBF } \\
(\text { (cc./min./1.73 sq. m. })\end{array}$} & \multicolumn{2}{c|}{$\begin{array}{c}\text { Mean arterial pressure } \\
(\mathrm{mm} . \mathrm{Hg})\end{array}$} \\
\cline { 1 - 2 } Mean & $\begin{array}{c}\text { Standard } \\
\text { error }\end{array}$ & Mean & $\begin{array}{c}\text { Standard } \\
\text { error }\end{array}$ \\
\hline 1,343 & -66 & 154 & 7 \\
1,729 & 147 & 144 & 6 \\
+386 & 134 & -10 & 6 \\
\hline \multicolumn{2}{|c|}{0.01} & & 0.13
\end{tabular}

\begin{tabular}{|c|c|}
\hline \multicolumn{2}{|c|}{$\begin{array}{c}\text { HPR } \\
(\mathrm{mm} . \mathrm{Hg} / \mathrm{cc} . / \mathrm{sec} . / 1.73 \mathrm{sq} . \mathrm{m} .)\end{array}$} \\
\hline Mean & $\begin{array}{l}\text { Standard } \\
\text { error }\end{array}$ \\
\hline $\begin{array}{r}7.1 \\
4.7 \\
-2.4\end{array}$ & $\begin{array}{l}0.5 \\
0.5 \\
0.6\end{array}$ \\
\hline & \\
\hline
\end{tabular}

TABLE III

The late contrasted with the early effects of splanchnicectomy on estimated hepatic blood flow (EHBF), arterial pressure, and hepatic-portal resistance $(H P R)$ in a group of six hypertensive patients

Before operation

Two weeks* after operation

Four-ten months after operation

Difference between preoperative and early postoperative

Significance of difference $(P)$

Difference between preoperative and late postoperative

Significance of difference $(P)$

\begin{tabular}{|c|c|c|c|c|c|}
\hline \multicolumn{2}{|c|}{$\frac{\mathrm{EHBF}}{(c c . / \mathrm{min} . / 1.73 \text { sq. m. })}$} & \multicolumn{2}{|c|}{$\begin{array}{c}\text { Mean arterial pressure } \\
(m m . H g)\end{array}$} & \multicolumn{2}{|c|}{$\underset{(m m . H g / c c . / s e c . / 1.73 \text { sq. m. })}{\text { HPR }}$} \\
\hline Mean & $\begin{array}{l}\text { Standard } \\
\text { error }\end{array}$ & Mean & $\begin{array}{c}\text { Standard } \\
\text { error }\end{array}$ & Mean & $\begin{array}{l}\text { Standard } \\
\text { error }\end{array}$ \\
\hline $\begin{array}{l}1,288 \\
1,954 \\
1,307 \\
+666\end{array}$ & $\begin{array}{r}76 \\
227 \\
126 \\
158\end{array}$ & $\begin{array}{r}168 \\
158 \\
157 \\
-11\end{array}$ & $\begin{array}{r}7 \\
7 \\
9 \\
11\end{array}$ & $\begin{array}{r}8.0 \\
5.3 \\
7.4 \\
-2.7\end{array}$ & $\begin{array}{l}0.5 \\
0.8 \\
0.6 \\
0.4\end{array}$ \\
\hline \multicolumn{2}{|c|}{$<0.01$} & \multicolumn{2}{|c|}{0.36} & \multicolumn{2}{|c|}{$<0.01$} \\
\hline+19 & 130 & -12 & 8 & -0.5 & 0.6 \\
\hline \multicolumn{2}{|c|}{0.89} & \multicolumn{2}{|c|}{0.23} & \multicolumn{2}{|c|}{0.46} \\
\hline
\end{tabular}

* This includes one patient studied $9 \frac{1}{2}$ weeks after operation. 
preoperative measurements in the same hypertensive patients.

3. Within four to ten months after splanchnicectomy EHBF and HPR in hypertensive patients return to their preoperative levels.

\section{ACKNOWLEDGMENT}

The authors gratefully acknowledge the assistance of Dr. Meyer H. Halperin in the preparation of the statistical tables.

\section{REFERENCES}

1. Culbertson, J. W., Wilkins, R. W., Ingelfinger, F. J., and Bradley, S. E., The effect of the upright posture upon hepatic blood flow in normal and hypertensive human subjects. J. Clin. Invest., 1947, 26, 1178.

2. Bradley, S. E., Ingelfinger, F. J., Bradley, G. P., and Curry, J. J., The estimation of hepatic blood flow in man. J. Clin. Invest., 1945, 24, 890.

3. Culbertson, J. W., Wilkins, R. W., Ingelfinger, F. J., and Bradley, S. E., The effect of the upright posture upon hepatic blood flow in normotensive and hypertensive subjects. J. Clin. Invest., 1951, 30, 305.

4. Wilkins, R. W., Culbertson, J. W., and Ingelfinger, F. J., The effect of splanchnic sympathectomy in hypertensive patients upon estimated hepatic blood flow in the upright as contrasted with the horizontal position. J. Clin. Invest., 1951, 30, 312. 